\title{
GERMAN-LANGUAGE CULTURE AND THE SLAV STRANGER WITHIN
}

\author{
Tim Beasley-Murray
}

University College London, School of Slavonic and East European Studies

THE aim of this article is to delineate the symbolic position of the Slavonic, and in particular the Czech, in German-language Austrian culture of the period I890-I940. My approach will be informed by psychoanalysis. A subsidiary aim is to try to demonstrate uses of psychoanalysis in the study of central European culture. What is at issue here is an historical set of social power relations that find their expression in culture, that is to say, in art and literature, and that can be interpreted by psychoanalysis. All too often psychoanalysis avoids the social and the political outside the framework of the individual and her or his predictable traumas emanating from domestic life. ${ }^{\mathrm{T}}$ This article, however, constitutes an exercise in inter- and intra-cultural psychoanalysis: intra-cultural as an investigation of psychoanalytic dynamics within German-language culture; inter-cultural as an examination of the relationship between German-language and Slav cultures in psychoanalytic terms.

Approaches to alterity: post-colonialism, orientalism, balkanism

A strand of recent scholarship devoted to the culture of the Habsburg Empire has focused on the extent to which the cultural and political relations between the various ethnic groups within the Monarchy can be characterized in terms of the vocabulary of post-colonial studies. Scholars have construed the Empire in terms of a linguistically and ethnically German centre of the Empire and Slav margins in the same way that post-colonial studies conceptualizes the relationship between European imperial societies and their colonized non-European subjects. ${ }^{2}$ As a result, much of the recent writing on Habsburg culture uses a discourse of

I I draw here on Deleuze and Guattari's objection to the domestication of psychoanalysis and the restriction of desire to the Oedipal triangle. Here the authors propose 'deterritorializing Oedipus into the world instead of reterritorializing everything into Oedipus and the family'. Gilles Deleuze and Félix Guattari, Kafka: Towards a Minor Literature, trans. by Réda Bensmaia, London, I986, p. Io.

2 Scholars associated with the internet-based research project, Kakanien Revisited, are foremost in this trend. See <http://www.kakanien.ac.at>. Scott Spector takes a similar approach in his Prague Territories: National Conflict and Cultural Innovation in Franz Kafka's Fin de Siècle, London, 2000, see particularly pp. I72-73. My reading of Broch below owes much to Wolfgang Müller-Funk's article, 'Kakanien Revisited: Über das Verhältnis von Herrschaft and Kultur' < http://www.kakanien.ac.at/beitr/theorie/WMueller-Funki.pdf. $>$ [accessed April 2 2006]. Where Müller-Funk, however, interprets Broch's description of the relationship between the German male subject and the Slav woman object as means of the construction of social hegemony, I am more interested in a psychoanalytical reading of relations of difference. 
alterity drawn from post-structuralist and feminist analyses of hegemony and difference. Critics argue that one can define a dominant German-speaking centre that constructs images of the subordinate groups within the Empire by means of asymmetrical hierarchies of difference. Thus German-language culture and Slavonic-language culture are viewed in terms of a set of familiar oppositions in which German-language culture occupies the privileged position. German culture is rational, domestic, and male. It represents civilization and progress. Slav culture is irrational, exotic and female. It represents Nature and myth. ${ }^{3}$

These scholars, however, fail to recognize the fact that there is no easy distinction between centre and periphery in the Habsburg Empire. This is particularly true of the Czechs and their position within the Empire. In the period under discussion here, the Lands of the Bohemian Crown were, in some senses, at least as central as the lands that make up today's Alpine Republic of Austria. ${ }^{4}$ In much of the Empire, Slavs (and other non-Slav nationalities) and Germans coexist historically and cannot be separated either by an East-West axis of difference or by a simple narrative of colonialization. ${ }^{5}$

Maria Todorova's introduction of the term 'balkanism' as an alternative to Edward Said's orientalism is useful here. For Todorova, the West is unable to hold the Balkans at arms length by means of simple oppositions because they are neither wholly European nor wholly oriental: 'Unlike orientalism, which is a discourse about an imputed opposition, balkanism is a discourse about an imputed ambiguity. [...] This inbetweenness of the Balkans, their transitory character, could have made them an incomplete other; instead they are constructed

3 The opposition of German/Slav, conceived in terms of civilization/Nature, male/female, and so forth, is established by Herder in the 'Slavenkapitel' of his Ideen in which the Slavs are, in part, described in natural and feminine terms. They are 'of a gentle disposition, hospitable to the point of wastefulness, lovers of their rural freedom, but subservient and obedient'. Johann Gottfried Herder, 'Ideen', in Herders Werke, ed. by Regine Otto, vol. 4, Berlin, Weimar, I982, p. 394. A gendered image of the Slavs persists in the writings of German thinkers and is also appropriated by Slav ideologues themselves. For a comprehensive overview of the German side of this tradition, see Ritchie Robertson, 'Zum deutschen Slawenbild von Herder bis Musil', in Urs Faes and Béatrice Ziegler (eds), Das Eigene und das Fremde. Festschrift für Urs Bitterli, Zurich, 2000, pp. I I6-44. Kurt Breysig supports the characterization of Slavs as female and Germans as male: 'The Slavs were entirely aptly called female nations in contrast to perfectly male nations such as the Germanic and Romance.' Breysig, quoted in Emanuel Moravec, Obrana státu, 5th edn, Prague, I937, p. I77. The locus classicus of Slav appropriation of a feminized identity in opposition to German masculinity and aggression is the Slovak writing in Czech, Jan Kollár's mythopoeic sonnet cycle of i 824-52, Slávy dcera (The daughter of Sláva).

4 Arguing against the discourse of centre and periphery, Luft demonstrates that one cannot speak of the Bohemian Lands as standing in a colonial relation to the German-speaking regions of the Empire in the late nineteenth century and suggests that 'the level of economic, political and cultural development of [the Bohemian Lands], combined with their stability, imply, on the contrary, the potential for imperial ambitions of their own'. Robert Luft, 'Machtansprüche und kulturelle Muster nicht peripherer Regionen: Die Kernländer Böhmen, Mähren und Schlesien in der späteren Habsburger Monarchie', in Johannes Feichtinger, Ursula Prutsch and Moritz Csáky (eds), Habsburg postcolonial. Machtstrukturen und kollektives Gedächtnis, Innsbruck, 2003, pp. I65-87 (I67).

5 The authors of the preface to an edited volume on the question of centres and peripheries in central Europe provide a more refined account of the problems of applying the logic of centre and periphery to Habsburg culture. Nevertheless, their recourse to a Deleuzian model of 'nomadological topographies' of shifting plateaux of dominance and subordination in order to replace the binary of centre and periphery does little to resolve the pertinent questions that they raise. See Endre Hars, Wolfgang Müller-Funk, Ursula Reber and Clemens Ruthner (eds), Zentren und Peripherien in Herrschaft und Kultur Österreich-Ungarns, Tübingen, 2005 , pp. I-I5. 
as an incomplete self.' ${ }^{\prime}$ The encounter with ambiguity in processes of identification takes place, however, not only in an encounter with the transitional margins. I deal here with Czechs, a group who have not been historically understood as only marginal or halfEuropean, and their representations in the German culture that occupies the same space. ${ }^{7}$ I reject the approach of the contributors to a recent collection of essays on Western representations of east European women whose essential emphasis is on the half-Asian, half-European nature of east European women as seen by Western writers. ${ }^{8}$ This article is not concerned, for example, with the unequivocal alterity of Slav femmes fatales who populate the novels of Joseph Roth. ${ }^{9}$ It is concerned with a far more intimate and hence uncanny fusion of the alien with the familiar. For my writers and their subjects do not belong to the margins. They belong to a geographical and cultural space that, whilst it may be internally differentiated, is fundamentally one. This essay concerns not the relations between western and eastern Europe but relations within central Europe. It seeks to adumbrate the ambiguities that structure the culture of Europe as a result of an intertwining of forces that can no longer be called simply central or peripheral.

\section{The stranger within: psychoanalysis}

Neither an analysis of German-Slav cultural relations along the lines of alterity alone, nor an analysis along the lines of mere inbetweenness, is sufficient to explain the complexity and ambivalence that marks German-language treatment of the Slav in the Habsburg and immediately post-Habsburg period. ${ }^{\text {Io }}$ For German-language writers of the Habsburg Empire, Slav culture occupies an unusual position by being both alien and familiar.

Slav culture was familiar to any German-speaking Austrian. He might be of Slav family origin himself. He may have spent his earliest years or done his military service in the Slavonic-speaking Kronländer. He may have heard Czech every day on the streets of Vienna or Prague. And yet, Slav culture would also most often have been alien to him. It was not his culture. It was not immediately comprehensible to him and also, in an era of increasing nationalism amongst the Slav Nationalitäten, it was threatening and, sometimes, alluring in its difference. Thus Slav culture played a role that saw it cast as both familiar and alien, domestic and exotic, central and peripheral. It was what one might term an internal other, and, for that

${ }^{6}$ Maria Todorova, Imagining the Balkans, Oxford, I997, pp. I7-I 8.

7 There are other instances where Slavs are often just as difficult to characterize in terms of marginality. The Poles of Galicia and Silesia sometimes fall into this category.

${ }^{8}$ See Valentina Glajar and Domnica Radelescu, Vampirettes, Wretches and Amazons: Western Representations of East European Women, Boulder, CO, 2004.

9 See, for example, the figure of the flame-haired revolutionary, Natascha, in Joseph Roth, Die Flucht ohne Ende (The flight without end, I927).

Io Marcus Reisenleitner similarly suggests that the Kakanien project's post-colonialist approach to Habsburg and post-Habsburg culture misses the complexity of its subject: 'I would rather propose to conceptualize a serious engagement with postcolonial theory not so much in terms of an application but rather as a project of juxtaposition that re-shuffles the deck and thus provides a platform for tangential and guerilla readings that do not fall prey to oversimplifications and remain stuck in legitimizing binaries of dominance and oppression.' He provides, however, little by way of outline of what such 'tangential' readings might be. Reisenleitner, "Central European Culture in Search of a Theory, or: The Lure of "Post/Colonial Studies"', in Spaces of Identity, 2, 2002, 2 <http://www.yorku.ca/soi/_Vol_2_2/_HTML/Reisenleitner.html> [accessed April 2 2006]. 
reason, an other that was more unsettling than the other that can be firmly held at arm's length by means of simple operations of difference.

This description of the position of Slav culture in the German-speaking Austrian mind points to the psychoanalytic understanding of the Unconscious. The Unconscious, too, is the internal other. The Unconscious is both that which is most intimately part of us and that which is most unknowable. It is at the same time alien and familiar. Its secret is the Oedipus complex. According to psychoanalysis, the desire to kill our fathers and sleep with our mothers is at once alien and repulsive to our conscious minds; and yet it is also the most banal and familiar of domestic dramas, common to us all. The Slav element in German culture functions in a similar fashion. It is what Julia Kristeva terms, 'the strangeness within' (l'étrange au-dedans de nous). ${ }^{\text {II }}$ Through consideration of these parallel relations of alterity and familiarity, then, we see how the Slav, as the stranger within, can come to represent the Unconscious and how the Unconscious can be represented by images of the Slav. ${ }^{\text {I2 }}$

The most extreme example of the way in which the Slav could come to stand for the repressed, on purely sociological grounds, is to be found in the pairing of the Czech nursemaid and the Czech prostitute. For many male members of the German-speaking Viennese upper-middle classes there were two ways in which they were likely to encounter Czechs: first, in the form of their Czech nursemaids, and, second, in the form of a Czech prostitute. In some instances these could be the same person. For example, Stefan Zweig in his memoirs of pre-First World War Vienna writes that some fathers dealt with the problem of their sons' sexual curiosity by hiring a maid (often a Czech, one must presume, given the huge numbers of Czech women in Vienna domestic service) whose job it was both to perform her normal duties and to provide sexual initiation for the son(s) of the house. ${ }^{13}$ Similarly, Pavel Eisner, writing about Prague rather than Vienna, notes that not only Czech women worked as cooks, servants and nursemaids in German bourgeois households, but that also the young German received his erotic initiation usually from Czech women. ${ }^{14}$ So where Zweig describes prostitution as a 'the dark cellar-vaults [...] above which, with its spotlessly dazzling

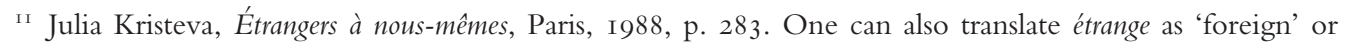
'alien'.

${ }^{12}$ Radulescu and Glajar also refer to east European women as 'strangers in our midst'. Nevertheless, their concentration on representations of subjects who come from 'remote regions' of liminality between Europe and Asia is at odds with this. My Slavs really are internal others. In Radulescu and Glajar's volume one can discern the negative influence of the currently modish preoccupation with travel writing which may sometimes blind scholars to the internal differences that exist under their noses. Habsburg German-speakers did not have to travel to encounter Slavs. See Valentina Glajar, "Half Asia”: Local Women at the European Periphery in German-language Travel Writings', in Glajar and Radulescu (eds), Vampirettes, Wretches and Amazons, pp. 9I-Io6.

${ }^{13}$ See Stefan Zweig, Die Welt von Gestern (The world of yesterday, I942), Frankfurt/Main, I970, p. Io I. For details of the Czech presence in Vienna at the time, see Monika Glettler, 'Minority Culture in a Capital City', in Robert B. Pynsent (ed.), Decadence and Innovation: Austro-Hungarian Life and Art at the Turn of the Century, London, I989, pp. 49-60.

I4 See Pavel Eisner, Milenky: německý básník a česká žena (Mistresses: the German writer and the Czech woman, I930), Prague, I992. Eisner's conception of the eroticized relationship between German writers and Czech women is an ambiguous and yet, in part, idealized conception of a dangerous but desirable union of the two cultures in symbolic and sexual embrace. Eisner was a Jewish German-Czech critic and translator who was genuinely equally at home in both languages and cultures, and this exceptional degree of cultural bilingualism means that, whilst his work displays many of the characteristics of the other texts discussed here, it also differs from these in its ability to see the relationship between Germans and Slavs from both sides. 
façade, rose the magnificent edifice of bourgeois society' ${ }^{15}$ the contents of this dark underworld of desire were often Slav. In the fusion of Czech prostitute and Czech nursemaid, whether actual or symbolic, we see the Slav functioning as the sociological incarnation of Oedipus, the forbidden fusion of the maternal and the erotic. ${ }^{16}$

To see this symbolic vocabulary in action and to observe the set of symbolic relations that emerges between German-language and Slav culture, I shall turn to literature. First, however, I shall discuss the Moravian-born Sigmund Freud and the curious role that the Slav plays as a symbol of the repressed in Freud's own biography and work. ${ }^{17}$

\section{Freud's Slav dreams}

In I93 I the town of Př́bor (Freiberg) decided to honour its most famous son. On October 25, a plaque was fixed on the wall of Freud's former family home to mark the occasion of his seventy-fifth birthday. The great man himself had been expected to attend the ceremony, but was prevented by sickness. In lieu of attending, he sent a letter in which he stated the following:

I left Freiberg at the age of three, visited it again as a sixteen-year-old during my grammar-school holidays, [...] and have not been back since. Much has happened to me in the intervening period. It is not easy for a seventy-five-year-old man to convey himself back into early childhold, whose rich content has left only a few remnants in his memory; and yet there is one thing of which I can be certain: deep buried within me there still lives the happy Freiberg child, the first-born son of a young mother who received his first inextinguishable impressions from this air and this soil. So allow me to end this message of thanks with cordial greetings to the town and its inhabitants. ${ }^{\text {I8 }}$

Despite this seemingly heartfelt statement, it is clear that Freud's relationship to the town of his birth and the Czech culture of which it was largely a part was ambivalent. The Freud family left Freiberg in I 859 when Freud was just short of his fourth birthday. The immediate reasons for the Freuds' move from Freiberg remain unclear. It seems that a combination of the commercial difficulties of Freud Senior's textile business and a rising tide of antisemitism in the region played its part and it is clear that the family left Moravia for anything but happy reasons. ${ }^{19}$ This same path was followed by many Habsburg Jews in the late nineteenth century who abandoned the Slavonic-speaking provinces for the liberalizing centre of Germanlanguage culture, Vienna. An analogous rejection of the Slav plays a role in Freud's dream representations of his desire for personal and scientific success.

is Zweig, Die Welt von Gestern, pp. I03-04.

${ }^{\text {I6 }}$ Müller-Funk notes that Slav women are usually represented in German literature of the period in two fashions: either as corrupt metropolitan fallen woman or as model of rural, maternal virtue (but in her purity, sexually alluring none the less): 'The other, alien woman [...] is submissive as whore, but also as mother, as lover, but also as earthy source of maternal milk.' Müller-Funk does not, however, draw the psychoanalytic conclusions that his comments indicate, but rather follows a post-colonialist ideology that is concerned with domination. Müller-Funk, 'Kakanien Revisited: Über das Verhältnis von Herrschaft und Kultur', p. 7.

${ }^{17}$ The importance of Freud's Jewishness to his ideas has been the focus of a great deal of comment. See, for example, Moshe Gresser, Dual Allegiance: Freud as a Modern Jew, New York, I994. As far as I am aware, nothing has been written about his admittedly much less strongly apparent Moravian identity.

I8 Sigmund Freud, 'Brief an den Bürgermeister der Stadt Přibor', in Gesammelte Schriften, ed. by Anna Freud,

E. Bibring, W. Hoffer, E. Kris and O. Isakower, Frankfurt/Main, I999, vol. XIV, p. 66I.

19 See Peter Gay, Freud: A Life for our Time, New York, I988, p. 8. 
Freud had, on the one hand, a desire to succeed professionally and intellectually and, on the other, a concomitant fear of failure. The great dream that provides much of the central material for Die Traumdeutung (The interpretation of dreams, I900), the dream of Irma's injection, expresses his anxiety lest he be committing medical malpractice as well as his desire to succeed. As Carl Schorske has persuasively argued, this desire is often expressed by means of a symbolic vocabulary that focuses on the image of Rome, the Eternal City, and draws on ideas of both archaeology and conquest. ${ }^{20}$

It was while working on Die Traumdeutung that Freud's interest in Antiquity and Rome arose. He hit upon the analogy between his procedure of digging into his own buried, mental past and the work of the archaeologist. To reveal what lies in the mind buried under layers of repression would be an achievement comparable to a perfect reconstruction of the archaeological strata of the Eternal City. The successful establishment of psychoanalysis would be the conquest of Rome. Soon his mild interest developed into an insatiable passion. He eagerly read the biography of Schliemann who fulfilled a childhood wish by his discovery of Troy. He began the collection of ancient artefacts that soon filled the office in the Berggasse. Freud made a new friend, Emanuel Löwy, a professor of archaeology: 'He keeps me up until three o'clock in the morning,' Freud wrote to his friend Fliess, 'he tells me about Rome'. ${ }^{21}$ Furthermore, Freud's fantasy of the conquest of Rome was not only connected to his ambitions on medical research. It was also connected to his social ambitions as a Jew. In Die Traumdeutung Freud also recalls his youthful identification with Hannibal, the Semitic conqueror of Rome. ${ }^{22}$

It is in this context that we must interpret the dream that Freud records concerning Prague and Rome:

A fourth dream [...] took me to Rome once again. I saw a street-corner before me and was astounded to see it plastered with German posters. Only a few days earlier I had written prophetically to my friend that Prague might not be an agreeable, comfortable place for a German to walk about in. The dream thus expressed both the wish to meet him in Rome rather than in a Bohemian city, and also my desire, probably dating back to my days as a student, for the German language to be shown more tolerance in Prague. ${ }^{23}$

The hapless dreamer ends up in a Rome that simultaneously signals a Prague that has become German. What we see here is an ambiguous wish-fulfilment: on the one hand, Freud has finally entered the Eternal City. ${ }^{24}$ His desire for success has been realized. On the other hand, one might interpret the identification between Rome and Prague as a way in which this dream of success is undermined by a sneaking sense of failure: Freud, it seems, sets out to

${ }^{20}$ See Carl E. Schorske, 'Freud: The Psychoarcheology of Civilizations', in Jerome Neu (ed.), The Cambridge Companion to Freud, Cambridge, I991, pp. 8-24.

${ }^{21}$ Quoted in ibid., p. I8.

${ }_{22}$ Malcolm Bowie discusses the connexion between Freud's 'Rome complex' and his 'conquistador complex'. See Bowie, 'Freud's Dreams of Knowledge', in Freud, Proust and Lacan: Theory as Fiction, Cambridge, I987, pp. I3-44.

23 Sigmund Freud, Die Traumdeutung, in Gesammelte Schriften, vol. II/II, I999, p. 20 I.

${ }^{24}$ As he points out later in the text, this dream is also the fulfilment of another desire: Freud had planned to meet his friend Fliess in Prague over Easter, I897. This meeting, longed for by Freud and scheduled during a period of the friendship's great intensity, never came about. See ibid., pp, 328-29, and Freud's correspondence on the matter collected in Jeffrey Moussaieff Masson (ed. and trans.), The Complete Letters of Sigmund Freud to Wilhelm Fliess, 1897-1904, Cambridge, MA, I985. Freud hints that the reason for the cancellation of the Prague meeting was connected to the unrest between Czechs and Germans caused by the Badeni crisis, p. 284. It appears that Freud never visited Prague. 
conquer Rome and only gets as far as Prague. Nevertheless, the Prague of the dream is a germanized city. Freud's desire to leave his provincial Moravian origins in order to find success in German-language culture is embodied in the germanization of the centre of Czech culture. In other words, despite all the emphasis on Rome in Freud's auto-mythology, his real fantasy city might be this German Prague from which the Slav element of failure has been repressed. It is also the fulfilment of the dreams of assimilated Jews like Freud who imagined that the liberal regime that promised them so much was threatened by the new surge of Czech political nationalism. (This dream was dreamed in I 897 soon after Prague riots over the non-implementation of the Badeni language decrees, by which Czech and German would have had equal status in Bohemia.)

Freud interprets the image of a germanized Prague as the embodiment of his early political desires. In this fantasy of a germanized Prague, just as in the fantasy of Rome, lies the concretization of a further wish for the success of psychoanalysis. For Freud, the Czech language is a symbol of childhood. The goal of psychoanalysis is to bring to consciousness and thus to make accessible to interpretation the experiences of childhood. By presenting an image of Czech culture, Prague, where all is comprehensible to him because it is in German, Freud is also presenting an image of a psychoanalysis that has succeeded in achieving this goal. The German posters of Freud's dream-Prague make the repressed readable and hence represent another fulfilment of the wish to succeed. This interpretation is strengthened by the subsequent words in the passage:

I must have understood the Czech language during the very first years of my life, since I was born in a small town in Moravia whose inhabitants are Slavs. A Czech nursery rhyme, that I heard when I was seventeen, imprinted itself on my memory with such lack of difficulty that I remember it to this day without having the slightest idea what it means. This dream is thus not lacking in numerous connexions to the impressions of my first years of life..$^{25}$

Freud claims to have forgotten the Czech language, and yet, Czech was an important part of his childhood. One of the central tenets of psychoanalysis is that no forgetting is innocent. All forgetting is the result of a movement of repression that is motivated by unconscious desires. Freud's ability to memorize a Czech nursery-rhyme is, then, a return of the repressed. This ability is, however, uncanny, since Freud is able to commit the rhyme to memory but is still unable to say what it means. Czech is both familiar from distant childhood and something that is alien and incomprehensible. It is, then, a sign of the Unconscious. Freud's dream embodies the wish to make the Unconscious readable, to expunge what is incomprehensible and alien in the familiar. For Freud, the Slavonic represents the repressed within German-language culture: an element of the alien within the familiar that Freud's theory seeks to domesticate.

\section{Kafka's Slav uncanny}

In one of Franz Kafka's short stories, 'Die Sorge des Hausvaters' (The concern of the head of the household, I9I9), we meet Odradek. What Odradek constitutes is difficult to determine:

At first glance, it looks like a flat star-shaped spool for thread, and indeed it does seem to have thread wound onto it; to be sure, they are only old, broken-off bits of thread, knotted and tangled 
together, of the most varied sorts and colours. But it is not only a spool, for a small wooden crossbar sticks out of the middle of the star, and another small rod is joined to that at a right angle. By means of this latter rod on one side and one of the points of the star on the other, the whole thing can stand upright as if on two legs. ${ }^{26}$

Constructed of objects, the detritus of domestic existence, sticks and string, Odradek is neither animate nor inanimate. Despite its or his (sein) wooden nature, it or he (er) is highly mobile and difficult to catch. He or it has limited powers of speech, but these powers do not confirm either way Odradek's status as animate or inanimate:

'Well, what's your name?' you ask him. 'Odradek,' he says. 'And where do you live?' 'No fixed abode,' he says and laughs; but it is only the kind of laughter that has no lungs behind it. It sounds rather like the rustling of fallen leaves. And that is usually the end of the conversation. Even these anwers are not always forthcoming; often he remains mute for a long time, as wooden as his appearance. ${ }^{27}$

Odradek is both familiar, part of the furniture, part of the household, we might say, and unfamiliar. He hangs around in the loft, on the stairs, in corridors, and thus occupies both the liminal and central places in the symbolic architecture of the house. Sometimes he moves into other houses for a while, but is soon to be found back in the house of the narrator. He is both part of the domestic scene and not part of it. The mystery is the question whether or not Odradek has a purpose:

One is tempted to believe that the creature once had some sort of intelligible shape and is now only a broken-down remnant. Yet this does not seem to be the case; at least there is no sign of it; nowhere is there an unfinished or unbroken surface to suggest anything of the kind; the whole thing looks senseless enough, but in its own way perfectly finished. ${ }^{28}$

The mystery of Odradek's antinomy of familiarity and strangeness might seem to lie in the past. Odradek might once have had a purpose that has been forgotten. Nevertheless, now there is no clue to such a purpose in Odradek's body that is both an assemblage of various fragments and a smooth, closed whole. Finally, Odradek is a painful reminder of the narrator's own mortality.

I ask myself, to no purpose, what is likely to happen to him? Can he possibly die? Anything that dies has had some aim in life, some activity that has worn out; but that does not apply to Odradek. Am I to suppose, then, that he will always be rolling down the stairs, with ends of thread trailing after him, right before the feet of my children, and my children's children? He does no harm to anyone that one can see; but the idea that he is likely to survive me I find almost painful. ${ }^{29}$

These four determinants of Kafka's Odradek (the antinomy animate/inanimate, the antinomy familiar/strange, the connexion with the forgotten events of the past, the memento mori) are also four of the central determinants of the sense of the uncanny as described in Freud's essay of the same name. ${ }^{30}$ In terms of Freud's theory of the uncanny, the aesthetic power of Kafka's

${ }^{26}$ Franz Kafka, 'Die Sorge des Hausvaters', in Sämtliche Erzählungen, Frankfurt/Main, I994, pp. I39-49 (I39).

${ }^{27}$ Ibid., p. I4O.

${ }^{28}$ Ibid., p. I39.

29 Ibid., p. I40.

${ }^{30}$ See Sigmund Freud, 'Das Unheimliche', in Gesammelte Schriften, vol. XII, I99I, pp. 227-68. Pierce also points out some of the determinants of the uncanny in Kafka's description of Odradek. The main point of his Lacanian interpretation, however, is that Odradek, as an ineffable phallic substitute, represents the 'presence of absence' to the father. Rolland Pierce, Odradek: Loi de Kafka, Paris, I976, pp. 39-40. 
story comes from its subtle drawing on the power of condensed and displaced unconscious energies in the strange figure of Odradek. And yet, we must ask what exactly we are to make of the curious name of Kafka's curious figure which is, perhaps, the uncanniest thing of all. The first paragraph of the story reads as follows:

Some say the word Odradek is of Slavonic origin, and try to account for it on that basis. Others again believe it to be of German origin, only influenced by Slavonic. The uncertainty of both interpretations allows one to assume with justice that neither is accurate, especially as neither of them provides an intelligent meaning of the word. ${ }^{31}$

Certainly, 'odradek' looks immediately like a Slavonic word. Its meaning, however, is not clear. In this sense, the problem of its etymology reiterates the uncanny: on the one hand, it looks familiar; it looks as if one (if one speaks Czech) should know what it means. On the other hand, it is indecipherable and alien; perhaps it is a word that one has forgotten; perhaps it is a word that one never knew. The uncertainty whether it is Slavonic or German is also a restatement of the uncanny.

As critics have intermittently pointed out, Kafka's texts on occasion display possible references to the Czech language. ${ }^{32}$ The name Kafka is, as Ritchie Robertson points out, derived from the Hebrew 'Yakov' (Jacob), but, nevertheless, 'kavka' is also the Czech word for jackdaw and a common Czech surname. ${ }^{33}$ Kafka plays with the Czech meaning of his name on a number of occasions. For example, the name, Gracchus, in the story 'Der Jäger Gracchus' (The huntsman Gracchus, I9I7) is etymologically related to the Latin word for jackdaw, 'graculus'. Similarly, the only named character in the story, 'Hochzeitsvorbereitungen auf dem Lande' (Preparations for a country wedding, I907-08), is called Raban, a name that may be linked to the German 'Rabe' (raven), a member of the family of birds to which the jackdaw belongs. The raven motif recurs in Der Prozeß (The trial, I925) where the black-clad men who come to arrest K. are called Kaminer, Kullych and Rabensteiner. Kullych is a German variant of the Czech 'kulich', the 'little owl', a bird that, like the raven, often signifies an ill omen. Likewise, the name Samsa, the main character of 'Die Verwandlung' (The transformation, I9I5), as a range of critics have suggested, may be associated with the Czech 'sám jsa' (where the ' $\mathrm{j}$ ' is not normally pronounced) which means 'being alone'. ${ }^{34}$ Hence, despite the narrator's warning of the futility of such attempts, it is worth considering what results if

${ }^{31}$ Kafka, 'Die Sorge des Hausvaters', p. I39.

${ }^{32}$ Nekula has made a valuable and detailed empirical study of the degree of Kafka's familiarity with Czech (on the basis of a linguistic analysis of a wide variety of documents and drawing on much archival material), emphasizing the degree both of Kafka's competence in Czech and his familiarity with Czech culture, thereby dispelling the legend of Kafka as the outsider in relation to Czech society and culture. See Marek Nekula, Franz Kafkas Sprachen. '. . in einem Stockwerk des inneren babylonischen Turmes ... .', Tübigen, 2003, and Marek Nekula, 'Franz Kafkas Sprachen und Identität', in Marek Nekula and Walter Koschmal (eds), Juden zwischen Deutschen und Tschechen. Sprachliche, literarische und kulturelle Identitäten, Munich, 2005, pp. I35-58. Antonín Měšt'an also discusses Kafka's references to Slav culture more generally in Měšt'an, 'Slované u Franze Kafky', in Měšt’an, Česká literatura mezi Némci a Slovany, Prague, 2002, pp. 38-67. The most comprehensive treatment of Kafka's references to the Czech language in the names of his characters is provided by Elizabeth M. Rajec, Namen und ihre Bedeutungen im Werke Franz Kafkas. Ein interpretatorischer Versuch, Frankfurt/Main, I977.

33 Ritchie Robertson, Kafka: Judaism, Politics, and Literature, Oxford, I985, p. 4.

34 See, for example, Max Brod, Über Franz Kafka, Frankfurt/Main, I974, p. I I9. 
one tries to explain the meaning of Odradek in terms of a Slavonic (in this case, Czech) etymology. ${ }^{35}$

As the narrator indicates, none of the possible interpretations based on Slavonic etymology fits exactly. ${ }^{36}$ Critics have pointed out some of the range of associative possibilities. These possibilities, in their incompatibility and inconclusiveness, contribute to the sense of uncertainty and uncanniness embodied in the story. Moreover, the possibilities themselves point at the unconscious repository of desire that words both conceal and reveal. The word echoes morphologically 'odsudek' (condemnation, judgement), formed from the verb 'odsoudit' (to condemn). ${ }^{37}$ Thus, for example, one derivation might be the verb 'odradit', meaning to advise or warn someone against doing something or simply to frighten off, where the noun 'odradek' would mean a piece of advice not to do something. This highlights the sense that Odradek might represent what is forbidden or secret. Another set of associations would lead to the noun 'pořádek', meaning order, as in the phrase, 'v pořádku', 'in good order'. Odradek, which contains the prefix 'od' and hence may signify a negative movement away, might then be interpreted as that which disrupts order, a principle of disorder, or perhaps that which cannot be ordered. This interpretation is bolstered when one is led by the association with the word 'řadit', meaning to classify, and 'přiřadit', meaning to ascribe something to something else. Odradek cannot be classified or ascribed to anything else.

In all these instances, the sense is preserved: Odradek is part of the life of the Unconscious. $\mathrm{He}$ is a hidden and repressed element in conscious life; yet, he also disrupts and cannot be comprehended by conscious life. He represents the libidinous element that threatens to disturb the household from within and that cannot be controlled by the Father of the house. Thus Odradek is related to the lascivious serving girls of Kafka's novels (whom one may presume to be Slavs) who disrupt the running of their households and draw the protagonists into dangerous games of illicit sexual desire..$^{8}$

35 Nekula suggests that the question of whether the name 'Odradek' is Slavonic or Germanic in origin is misleading. In the physical description of Odradek he sees a sign of Jewishness: 'Whoever has seen such a ball of twine and has a little bit of imagination will quickly realize that Odradek most probably has the form of the Star of David. [...] It is important that [...] nothing more is said about the world of appearances of the word "Odradek" that might be either Germanic or Slavonic, but rather what follows concerns the being of Odradek that is defined in this way as Jewish.' Nekula, Franz Kafkas Sprachen, p. I 8. This interpretation fits in with the association of 'odradek' with 'odsudek'. Judgement and condemnation (Urteil, Verurteilung) are central themes in Kafka's work. Odradek, as a Jewish element, is there to be judged by Czech and German alike.

${ }^{36}$ Ehrich-Haefli attempts to interpret 'Odradek' along Germanic etymological lines. Her interpretation is thought-provoking but strained: 'Die erste Silbe od-, in Anlehnung an "öd" [...] würde soviel bedeuten wie "verlassen", "ermangelnd"; die Silbe -rad- bezeichnet das Kreisrund der flachen Zwirnspule; ein -ek, ein Viereck entsteht durch je rechtwinklige Anfügung der beiden Hölzchen.' Verena Ehrich-Haefli, 'Bewegungsenergien in Psyche und Text. Zu Kafkas "Odradek",, in Zeitschrift für deutsche Philologie, Io9, I990, 2, pp. 238-53 (242). Krock also follows a Germanic etymological path, suggesting that the combination of 'Rad' (wheel) and 'E(c)k' (corner or point) implies the incomprehensible coexistence of what is round and what is pointed. Marianne Krock, Oberflächen und Tiefenschicht im Werk Kafkas. Der Jäger Gracchus als Schlüsselfigur, Marburg, I974, pp. 85-86.

${ }^{37}$ My suggestions here build on, but also modify those first made in Wilhelm Emrich, Franz Kafka, Frankfurt/Main, I957, pp. 92-96, and developed elsewhere, for example by Rajec in her Namen und ihre Bedeutungen im Werke Franz Kafkas, pp. 4I-43. Nevertheless, my interpretation of the Slavonic as uncanny and a sign of the repressed does not find a parallel in these studies.

${ }_{38}$ See, for example, the figure of the serving girl, Leni, in Kafka's Der Prozeß. 


\section{Broch's Slav Oedipus}

In the first novel of Hermann Broch's trilogy, Die Schlafwandler (The sleepwalkers, I93 I-32), we encounter the young Prussian nobleman and officer, Joachim von Pasenow. At the beginning of the story, Pasenow is visited in Berlin by his father, the owner of a large estate in Stolpin in East Prussia. On such visits his father insists on being shown the seamier side of Berlin night-life. Unwillingly, Pasenow takes his father to the Jägercasino where father and son meet Ruzena (Růžena), a Czech prostitute. Ruzena reminds both Pasenow and his father of the Polish peasant women who live on their estate:

Meanwhile the two girls had sat down, and Ruzena began to talk in a deep voice, laughing at herself, since she had not yet learned to speak German properly. Joachim was annoyed at his father for conjuring up the memory of the Polish girls, but was himself forced to think of one of the harvest workers, who, when he was a little boy, had lifted him up onto the cart with the sheaves. Yet though in her hard, staccato pronunciation she mixed up all her articles and spoke wrongly of 'die Direktor' and 'das Stadt', still she was a young lady, stiffly corseted, who lifted her champagneglass to her lips in the proper style, and so was not in the least like a Polish harvest worker; whether the talk about his father and the maids was true or not did not make any difference to Joachim, but this gentle girl was not to be treated by his father in the way in which he was perhaps accustomed to. All the same Joachim was unable to envisage the life of a Bohemian girl as any different from that of the Polish girls - indeed, even in the case of German civilians it was difficult to imagine the living being behind the puppet - and when he tried to imagine Ruzena as coming from a good home, with a good matronly mother and a good suitor with gloves, it did not add up, and Joachim could not rid himself of the feeling that in Bohemia life must be low and wild, as among the Tatars. He was sorry for Ruzena, although she reminded him of a crouched beast of prey in whose throat a dark cry is strangled, dark as the Bohemian forests, and he longed to know whether one could talk to her as one talked to a lady, because all this was so terrifying and yet seductive, and in a way justified his father and his dirty intentions. ${ }^{39}$

In this passage, we see a model of the encounter between Slav and German culture that mirrors the 'psychical apparatus' described by Freud. The German language and the trappings of fine clothes and fine champagne function as the thin layer of Ego. Beneath these trappings, however, Ruzena is the cry of the beast of prey and the darkness of the Bohemian forests. ${ }^{40}$ Ruzena, however, represents rampant female sexuality not merely as the alluring and threatening other but also as part of Pasenow's psyche. She evokes the childhood memory of the Polish harvest-worker and the sensuous experience of a child being cradled by a mother figure. The image of Ruzena becomes the fusion of prostitute and nursemaid: that is to say, Ruzena becomes what is most uncanny and violently repressed of all, the projection of the oedipal desire for the mother. Forbidden lust and mothering are merged. In an encounter with a Czech lover oedipal desire is revived.

Ruzena, the sexually thrilling Czech prostitute whom decent society and convention prohibit (one thinks here of the interpretation of 'odradek' as a piece of advice not to do something), stands in opposition to Elisabeth, the chaste German noblewoman suggested as a potential bride by Pasenow's father. To remain with Ruzena is to refuse to accept the law of

39 Hermann Broch, 'Pasenow oder die Romantik', in Die Schlafwandler: Eine Romantrilogie, Frankfurt/Main, I994, pp. 9-I80 (20-2I).

$4^{\circ}$ The description of Ruzena as a beast of prey is reminiscent of Kafka's raven and owl that I have referred to above. The Id, as a beast or bird of prey, is always ready to pounce when least expected, just as Rabensteiner and Kullych in Der Prozeß pounce on Josef K. while he is still in bed. 
the father and to redirect his desire from the oedipal object. To take Elisabeth's hand in marriage is to accept symbolic castration at the hand of the father. It is from this that follows the arid sexlessness of his eventual union with Elisabeth..$^{4 \mathrm{I}}$ At the end of the novel, then, Pasenow rejects the call of Ruzena's wild, dark sexuality and capitulates to the law of the father. The novel ends with the scene of Pasenow and Elisabeth's wedding night. Needless to say, there is none of the passionate love-making that Pasenow enjoyed with Ruzena. Instead we see the newly married couple in their bedchamber nervously skirting around the fact that neither feels sexual desire for the other. Elisabeth lies naked in bed; Pasenow kneels on the floor beside her, fully-clothed:

'Forgive me,' he said again and knelt down to kiss the white, blue-veined hand on the edge of the bed farewell. She did not know if this was meant to signify the approach that she feared or not, and she remained silent $[\ldots]$ He would not let her hand go, despite the fact that he was by now quite impatient to leave the room. 'Elisabeth, say something,' he said, and Elisabeth answered slowly, as if they were not her words: 'We are not strange enough and we are not familiar enough to each other.' ${ }^{42}$

Elisabeth, the sanctioned compromise of the castration complex, has none of the unconscious power that results from the coexistence of the extremes of the familiar and the exotic.

Broch's Slav Oedipus is not an isolated phenomenon. In Robert Musil's work, Slav women come to represent the wish-fulfilment of oedipal fantasy. ${ }^{43}$ In Die Verwirrungen des Zöglings Törle $\beta$ (The confusions of young Törle $\beta$, I906), Božena is the tired-out Czech prostitute who is the focus of the young hero's awakening to sexuality, and yet who can never be dissociated from the image of Törleß's mother: 'Törleß feasted his eyes on Božena and at the same time was unable to forget his mother'. ${ }^{44}$ Furthermore, as Matthias Luserke has noted, the leitmotiv of fragrance that runs through the novel links mother and Slav prostitute in an oedipal circle..$^{45}$ Another example is the fallen-woman, Tonka, in Musil's novella of the same name (I924),

${ }^{41}$ Eisner's comments on the relation between the German writer and his Slav mistress in general are pertinent to the specific characters of this novel: 'The writer flees his Slav mistress and chooses an easier path, for he lacks the strength to overcome his internal conflict.' Eisner, Milenky, p. 22.

${ }_{42}$ Broch, Die Schlafwandler, p. I76.

43 Stern is one of few critics to locate Musil's Die Verwirrungen des Zöglings Törleß in its cultural and social context and notes the unsettling effect of relations of desire between Germans and Slavs. He comments: "the location is given in the first sequence of the book: "A small station on the railroad that leads to Russia", at the "outer edge" of Central Europe; and the subsequent description is permeated by indications of remoteness, alienness, of an inhospitable and outlandish atmosphere. We are placed at the point where the outposts of Occidental (that is German) culture meet the mysterious Slavonic East. [. . .] Living in a sea of Slav (Moravian) labourers and peasants, the German élite group depends on them materially and sexually, but through the sexual link insecurity is carried into its ranks.' J. P. Stern, 'The Education of the Master Race', in The Heart of Europe: Essays on Literature and Ideology, Oxford, I992, pp. 78-93 (79-80). Nevertheless, it must be pointed out that, if we are to give credence to the autobiographical element in Musil's novel, the location of Törleß's boarding school might be associated with Mährisch-Weißkirchen (Hranice), only thirty kilometres from the city of Olomouc/Olmütz and about eighty from Brno/Brünn. The Moravia of Mährisch-Weißkirchen is scarcely the wild borderlands between Austrian Poland and Russia to which, for example, the hero of Joseph Roth's Der Radetzkymarsch (The Radetzky March, I932) is posted for his military service. The town of Musil's novel is at the same time an alien and inhospitable environment and the bearer of the signs of everyday (ethnically German) Habsburg normality: a smartish café on the main square, a shop that sells luxury goods, and so forth.

${ }_{44}$ Robert Musil, Die Verwirrungen des Zöglings Törleß, Hamburg, 2002, p. 38

${ }^{45}$ Matthias Luserke, Robert Musil, Stuttgart, I995, p. 23. 
who acts as a mother and a lover for Musil's male hero and who in turn is idolized and finally destroyed by him. ${ }^{46}$ Similarly, the Czech nursemaid, Barbara, in Franz Werfel's autobiographical Barbara oder die Frömmigkeit (Barbara, or piety, I929), is, on the one hand, a maternal symbol of piety who replaces the protagonist's real mother in his affections; on the other hand, however, it is she who awakes the flame of desire that drives both the narrator and his protagonist. ${ }^{47}$

The bourgeois Austrian was often, like Werfel, the son of two mothers: one, the (Germanspeaking) biological mother, and the other, the maternal substitute represented by the (often Czech) nursemaid or nanny. This was true of Freud whose much-loved nanny seems to have been Monika Zajíc(ová), a member of the Czech family who lived in part of the same house as the Freud family in Freiberg. ${ }^{48}$ Peter Gay notes: 'Like some figures who were to engross his fantasy life later - Leonardo, Moses, to say nothing of Oedipus - the young Freud enjoyed the ministrations of two mothers. ${ }^{49}$ Secondary mother-figures of nursemaids and nannies, as figures of childhood sexual fantasy or even as sexual initiators, assist and reinforce the son's oedipal desire. In his own case, Freud refers to Zajíc(ová) somewhat obscurely as his 'prime originator' and his 'teacher in sexual matters'..$^{\circ}$ There are two points to be made here: first, it is the institution of nursemaids and nannies that provides a crucial social background to Freud's formulation of the Oedipus complex. Second, given that those nursemaids and nannies were most frequently Slavs, it follows that, in Eisner's words, '[the German writer] greets in his Czech mistress a sister of those nursemaids, nannies and servants who accompanied his childhood and left in him ineradicable traces', and that the reinvigoration of those traces involves the reinvigoration of oedipal desire..$^{51}$

\section{Conclusion}

I have been able to sketch only the outline of the phenomenon of the Slav 'stranger within' in the works of a few of the major writers of the period. ${ }^{52}$ It remains the case that the heart of this

${ }^{46}$ See Robert Musil, 'Tonka', in Drei Frauen [1924], Hamburg, I972, pp. 46-86.

47 See Franz Werfel, Barbara oder die Frömmigkeit, Frankfurt/Main, 20oo, especially pp. 33-37. Werfel's novel is dedicated to the memory of his own nursemaid, a Czech woman, Barbora Šimůnková. Eisner notes that in Werfel's depiction of Barbara 'eroticism is sublimated into a powerful monument to the maternal instincts in Slav womanhood'. Eisner, Milenky, p. 23.

${ }^{4}$ For details of this and an interpretation of Freud's memories of Zajíc(ová), see Lisa Appignanesi and John Forrester, Freud's Women, London, I992, pp. I6-I8.

49 Gay, Freud, p. 7.

so See Freud's letter of October 3 I897, in The Complete Letters of Sigmund Freud to Wilhelm Fliess, pp. 267-70.

ऽI Eisner, Milenky, pp. I07-08.

52 Beside an extension of such an approach to other writers, related topics would also include the possibility of the existence of a similar dynamic between German-language culture and the other nationalities of the Empire, such as the Hungarians. More instructive, perhaps, might be an analysis of the ways in which Slav cultures themselves perceive elements of other Slav cultures as similarly both alien and domestic. In the Czech writer, Richard Weiner's, 'Kostajnik', a half-remembered Serbian place-name and its half-deciphered significance plays just such a role. See Richard Weiner, 'Kostajnik' [I9I6], in Netečný divák a jiné prózy, Prague, I996, pp. 270-93. 
phenomenon are social and political relations of power. ${ }^{53}$ These are relations of class, gender and nationality in which the objects of its images, such as Ruzena, are always in the subaltern position. Broch and others use the relationship between the German and the Slav to project personal and social anxieties and desires. The images that result, however, are the projections of dominant, privileged and, especially, male subjects. We see this in the following passage:

It occurred to him confortingly that one can only love a being from an alien world. That was why he could never love Elisabeth and why Ruzena had to be a Czech. Love means fleeing from one's own world into that of the other, and that's why, despite all his shameful jealousy, he had left his Ruzena in her own world so that she could flee to him, always new and always sweet. ${ }^{54}$

Here, Ruzena is the manipulated product of Pasenow's needs. In projections like these, the other does not have a voice except in so far as it is ventriloquized by the voice of the privileged subject's unconscious desires and fears. The reality of the situation was probably rather different. Broch's Ruzena, one must presume, became a prostitute, not in order to satisfy Pasenow's unconscious needs, but like thousands of Slav women of the period, for social and economic reasons. Eisner drily comments, it seems that these women and mistresses gave more than they received'. ${ }^{55}$

A psychoanalytical approach, however, reveals the ambivalence and complexity inherent in such relations of power, deepens our understanding of them, and perhaps points beyond them. Kristeva sees in the phenomenon of the stranger within the seeds of a utopia without hierarchy:

The strange [l'étrange] is in me, hence we are all strangers [des étrangers]. If I am a stranger, then there are no strangers. This is not the way that Freud speaks. Yet, the ethics of psychoanalysis imply a politics: this would be a matter of a new form of cosmopolitanism that, transcending governments, economies and markets, works for a humanity whose solidarity is founded on the consciousness of one's unconscious: desirous, destructive, fearful, empty, impossible. ${ }^{56}$

This form of higher cosmpolitanism does not characterize the relations between Germanlanguage culture and the Slavonic in the material that I have discussed in this article. ${ }^{57}$ Nevertheless, Kristeva's comments on the strangeness within point to a more benign model of relations between self and other that need not be cast in terms of manipulation and domination.

Finally, I return the question of what this investigation has told us about psychoanalysis. Psychoanalysis finds its origin in the social conditions of the specific place and time that was

53 In an article that deals with German writers' eroticized portrayal of Czech women in an eroticized Prague, Escher notes that that the 'topos of the German writer who conquers the woman and the city at the same time is, in its comforting triviality, the clear voice of a discourse of domination'. Georg Escher, 'Prager Femmes fatales: Stadt, Geschlecht, Identität' < http://www.kakanien.ac.at/beitr/fallstudie/Gescher.pdf> [accessed April 2 2006], p. 6.

54 Broch, Die Schlafwandler, p. 57.

$5 s$ Eisner, Milenky, p. Iо6.

${ }^{56}$ Kristeva, Étrangers à nous-mêmes, p. 284.

57 Müller-Funk rejects Kristeva's approach to alterity because of what he sees as its utopian reduction of the political relations of power and difference to mere psychological phenomena. Nevertheless, Kristeva's position is useful at least as a vantage point from which to evaluate such relations of power. See Wolfgang Müller-Funk, 'Das Eigene und das Andere/Der, die, das Fremde. Zur Begriffserklärung nach Hegel, Levinas, Kristeva, Waldenfels', in Feichtinger, Prutsch and Csáky (eds), Habsburg postcolonial, pp. 83-95, especially 86-88. 
late nineteenth-century Austria-Hungary. Psychoanalysis may be seen as both a symptom of and a cure for a socially and historically specific malaise. The arguments that suggest that the opening up of the unconscious is enabled by the discrepancy between the respectable façade of Habsburg Vienna and its eroticized underbelly are familiar. ${ }^{58}$ An alternative suggestion is made by Jacques Le Rider. Noting the importance of the 'Habsburg myth' that consisted in the mystical sacrificium nationis that demanded the individual transform himself from a German or a Czech into an 'Austrian', Le Rider argues that this 'myth' leads to 'political stagnation' which corresponds to 'a model of human behaviour, an ethics of the extinction of the passions, and a recourse to exterior and bureaucratic order'. ${ }^{59}$ The implication, then, is that the subordination of separate and plural national and cultural identities to a unified Austrian idea is analogous to the subordination of plural unconscious desires to the dictates of a unified Ego by means of repression: 'one might suggest that the Habsburg myth insinuates its way into psychoanalysis in the form of the hierarchical topography of the unconscious and in the form of the resigned and disenchanted adoption by the Freudian model of the equation of individual and the socio-political order'. ${ }^{60}$ The repression of the Slav in German-language culture might itself be one of the moments in the over-determined birth of psychoanalysis.

Musil's narrator comments in Der Mann ohne Eigenschaften (The man without qualities, published in two volumes, I930, I932; closer to complete publication, I943):

\begin{abstract}
Austria was known in the language of bureaucracy as 'The kingdoms and provinces represented in the Reichsrat', which, of course, meant nothing at all [.. .] If one asked an Austrian what he was, of course he could not answer: I am someone from one of the kingdoms and provinces represented in the Reichsrat [...]; and so that is why he preferred to say: I am a Pole, a Czech, and Italian, a Friulian, a Ladiner, a Slovene, a Croat, a Serb, a Slovak, a Ruthene, or a Romanian, and that was so-called nationalism. One might imagine a squirrel or a chipmunk that does not know that it is a squirrel or a chipmunk, a being that has no conception of itself. As a result, one will be able to see why, under certain circumstances, it can get into an uncontrollable panic at the sight of its own tail..$^{61}$
\end{abstract}

There is perhaps no better image of the subject of psychoanalysis than that of the squirrel or chipmunk that does not know what he or she is and is thrown into hysterical panic at the sight of his or her own tail. This is an image of the conscious mind startled by the return of the repressed. Here, the subject confronts the sight of the stranger within. On a larger scale, it is possible to see the repression of the culture of the (largely Slav) Nationalitäten and their uncanny return as instrumental in the creation of the psychoanalytic subject.

$5^{8}$ For example, such arguments are made in Allan Janik and Stephen Toulmin, Wittgenstein's Vienna, Chicago, I996, pp. 46-47.

59 Jacques Le Rider, Modernité viennoise et crises de l'identité, Paris, I990, p. 25. In a similar vein, Johnston observes the role of the highly regulated and bureaucratic nature of Habsburg society in the formulation of Freud's theory of the 'psychical apparatus'. William M. Johnston, The Austrian Mind: An Intellectual and Social History 1848-1938, London, I972, pp. 239-40.

${ }^{60}$ Le Rider, Modernité viennoise, p. 25.

${ }^{61}$ Robert Musil, Der Mann ohne Eigenschaften, Hamburg, I997, p. 45 I. 